Research Report No. 26/2012

\title{
Accountability Across Borders: Mining in Guatemala and the Canadian Justice System
}

Shin Imai

Osgoode Hall Law School of York University, simai@osgoode.yorku.ca

Bernadette Maheandiran

Valerie Crystal

Follow this and additional works at: http://digitalcommons.osgoode.yorku.ca/clpe

\section{Recommended Citation}

Imai, Shin; Maheandiran, Bernadette; and Crystal, Valerie, "Accountability Across Borders: Mining in Guatemala and the Canadian Justice System" (2012). Comparative Research in Law \& Political Economy. Research Paper No. 26/2012.

http://digitalcommons.osgoode.yorku.ca/clpe/28 


\section{OSGOODE}

\section{OSGOODE HALL LAW SCHOOL}

Comparative Research in Law \& Political Economy

RESEARCH PAPER SERIES

Research Paper No. 26/2012

\section{Accountability Across Borders: Mining in Guatemala and the Canadian Justice System}

Shin Imai, Bernadette Maheandiran and Valerie Crystal

\section{Editors:}

Peer Zumbansen (Osgoode Hall Law School, Toronto, Director Comparative Research in Law and Political Economy)

John W. Cioffi (University of California at Riverside)

Leeanne Footman (Osgoode Hall Law School, Toronto, Production Editor)

Comparative Research in Law \& Political Economy 


\section{Accountability Across Borders: Mining in Guatemala and the Canadian Justice System}

By Shin Imai, Bernadette Maheandiran and Valerie Crystal ${ }^{*}$

\section{INTRODUCTION}

Canada is one of the world's leading mining nations and one of the largest investors in Latin America. The Toronto Stock Exchange is a global centre for raising financing for mines, listing 54 percent of the world's public mining companies and, in 2011, trading over $\$ 450 \mathrm{~B}$ in mining equity. ${ }^{1}$ In Toronto, there are more than "400 mining and exploration company offices, over 30 mining company head offices and several hundred mining suppliers, consulting firms and service providers." ${ }^{2}$ Government statistics show that there are over 1,000 Canadian mining companies operating in over 100 countries with assets abroad worth over $\$ 129$ billion. Almost 50 per cent of the assets are in Latin America and the Caribbean. ${ }^{3}$

Mining is an inherently intrusive activity, both for the environment and for communities living on potential mine sites. Because of this, mines often attract controversy. Canadian mines have had their share of attention, and some in the industry have attempted to analyze the problem. $^{4}$

In this chapter, we will look at the history of one particularly troubled nickel mine in Guatemala, located near the town of El Estor. The mine was born into violence as Indigenous

\footnotetext{
* Shin Imai, Associate Professor, Osgoode Hall Law School of York University. Bernadette Maheandiran, Swadron Associates. Valerie Crystal, student at law, Osgoode Hall Law School. The authors would like to thank the following students for research assistance: Justin Dharamdial, Sarah Molyneaux, Sara Rohani and James Roundell. This article is an initiative of the Justice and Corporate Accountability Project at Osgoode Hall Law School. This chapter will be published in Obi Aginam, ed., Transnational Corporations, Human Rights and Environmental Justice in Latin America (Tokyo, United Nations University Press: forthcoming)

1. TMX, "Global Leaders in Mining", online: <http://www.tmx.com/en/listings/sector_profiles/mining.html>.

2. Mining Association of British Columbia, "Mining in Canada", online: 〈http://www.mining.bc.ca/facts_canada.htm〉.

3. "The Geographical Distribution of Canada's Mining Assets Canada's International Presence in 2010", online: Natural Resources Canada <http://www.nrcan.gc.ca/minerals-metals/publications-reports/4425>.

4. A report commissioned by the Prospectors and Developers Association of Canada was leaked in 2010. The report was very critical of the Canadian mining industry, but the PDAC claimed that it was unhappy with the methodology and did not accept the results. See "Canadian mining firms worst for environment, rights: Report", October 19, 2010, http://www.thestar.com/news/canada/article/877438--canadianmining-firms-worst-for-environment-rights-report
} 
people living on the site were removed to make room for the mine and the town. Numerous murders, assaults and other human rights violations have occurred as a result of the conflict between local Indigenous people who have historically lived in the area and the successive Canadian corporate entities - INCO, Skye Resources, and HudBay Minerals, as well as their Guatemalan subsidiaries. For example, two academics who voiced opposition to the mine were assassinated in 1969, seven men were killed between 1978 and 1981, eleven women were allegedly raped during 2007 evictions of the area, and a community leader was killed and another local man was maimed during protests against the mine in 2009.

There are currently three lawsuits filed against HudBay Minerals relating to the recent rapes and shootings. However, under current Canadian law, a court is not required to hear these cases on their merits if it finds that a Guatemalan court would provide a more appropriate forum or if the Canadian mining company does not owe a duty of care to the Guatemalan people who are affected by their operations.

In Canada, political solutions have been proposed that would have provided some scrutiny of the conduct of Canadian mining companies abroad. These have been vigorously opposed by the mining industry and have not been implemented. The Canadian government, through its ambassadors, has been unfailing in its support of the mines. One ambassador, in his attempt to stifle criticism of the Canadian mine, even slandered a filmmaker who documented the destruction of homes during one of the evictions. Although mine-affected communities have sought justice in Canadian courts, the courts have largely been unwilling to hear these cases on the merits. There is now accountability gap in respect of Canadian mining companies, and we argue that, until a better solution is found, Canadian courts should be more active in scrutinizing the conduct of Canadian corporations.

\section{FOREIGN INTERESTS AND GUATEMALAN HISTORY ${ }^{5}$}

Guatemala is a country that is predominantly Indigenous. It has 24 language groups with 52 distinct languages. ${ }^{6}$ About 60 per cent of the population identifies itself as Indigenous and continues to wear their traditional dress and speak their own languages. It is likely that a much

5. This section is based in part on Shin Imai, Ladan Mehranvar \& Jennifer Sander, "Breaching Indigenous Law: Canadian Mining in Guatemala" (2007) 6 Indigenous Law Journal 101, section II.

6. Raymond G Gordon Jr., ed., Ethnologue: Languages of the World, 15th ed. (Dallas: SIL International, 2005). 
higher percentage of the population is actually Indigenous, but does not identify as such. Being Indigenous is a bar to "getting ahead."7

Although Indigenous people have survived in Guatemala, it has been a precarious existence. Guatemalan society has historically been dominated by a small group of descendants of Spanish settlers who have been allied with the military and foreign interests. In 1951, when populist president Jacobo Arbenz took office, he began land reforms which would have appropriated uncultivated land from private companies and returned it to peasant farmers. ${ }^{8}$ The powerful United Fruit Company was one of the private interests affected. Despite receiving adequate compensation for its land in the southern part of Izabal, the United Fruit Company sought the assistance of the United States government to stop these reforms, accusing Arbenz and his government of being communists. ${ }^{9}$ With the financial and military backing of the American Central Intelligence Agency (“CIA”), Castillo Armas invaded Guatemala from Honduras in 1954. ${ }^{10}$ Armas' leadership favoured foreign investment and reversed the many beneficial social reforms that had been developed under Arbenz. ${ }^{11}$

Repression and economic disparity grew even more severe over the following years and guerrilla armies were established, made up largely of Indigenous people. A civil war began in 1960. It was a brutal, one-sided war. The guerrillas were no match for the American armed and trained Guatemalan military. ${ }^{12}$ Over 200,000 people were killed or went missing and a million people were displaced. ${ }^{13}$ Of the 42,275 registered acts of violence, 85 per cent of the killings were committed by the Guatemalan army, either acting alone or with other forces. ${ }^{14}$ One of the gruesome tactics employed by the army was a campaign to massacre Indigenous villages. The

7. Rachel Sieder, "The Judiciary and Indigenous Rights in Guatemala” (2007) 5:2 Int'1 J Const L 211 at 240 [Sieder, "Guatemala Judiciary"]. Sieder refers to the "innate racism" that pervades most of Guatemalan society as a reason that the judiciary has not taken a "proactive role in defense of [T]ndigenous rights."

8. Laura Moye, "The United States Intervention in Guatemala" (1998) 73:1 \& 2 Int'l Social Science Rev 44 at 45.

9. Ibid. At the time, there were close ties between the U.S. government and United Fruit. For example, President Eisenhower's personal secretary was married to United Fruit's press director, and the U.S. ambassador to the United Nations was a United Fruit stockholder. The U.S. Secretary of State and the CIA director also had "large investments in firms with a stake in United Fruit": Liza Grandia, Enclosed: conservation, cattle, and commerce among the Q'eqchi' Maya Lowlanders (Seattle: University of Washington Press, 2012) at 47.

10. Ibid at 44 .

11. Ibid.

12. Andrew J. Schlewitz, "Imperial Incompetence and Guatemalan Militarism, 1931-1966" (2004) 17:4 Int'1 J Politics, Culture and Society 585 at 600. Ironically, both Arbenz and Armas were graduates of a US-directed military training program.

13. Guatemalan Commission for Historical Clarification (CEH), Guatemala: Memory of Silence, online: American Association for the Advancement of Science (“AAAS"), Science and Human Rights Program <http://shr.aaas.org/guatemala/ceh/report/english/toc.html> [CEH Report (1999)]; Patrick Ball, Paul Kobrak \& Herbert Spirer, "State Violence in Guatemala, 1960-1996: A Quantitative Reflection" (Washington, D.C.: American Association for the Advancement of Science, 1999), online: AAAS <http://shr.aaas.org/guatemala/ciidh/ qr/english/en_qr.pdf $>$ ).

14. CEH Report (1999), ibid at <http://shr.aaas.org/guatemala/ceh/report/english/graphics/charts/ page86.gif>. 
atrocities that were committed during these massacres included the amputation of limbs, killing of children, victims being burned alive, and the removal of organs from live victims. ${ }^{15}$

The Canadian mining company, INCO, ${ }^{16}$ first became involved in Guatemala in 1960, when it created the subsidiary Exmibal with the U.S.-based Hanna Mining Company. ${ }^{17}$ INCO's involvement in Guatemala was part of a corporate strategy to maintain its position in the world nickel market by investing heavily in foreign ventures. ${ }^{18}$ At the time, the Canadian Department of External Affairs was very supportive of the idea of INCO's activity in Guatemala, believing that it would benefit Canadian exporters and increase Canada's prestige in Guatemala. ${ }^{19}$ Canadian diplomats relied on connections to push INCO's cause in Guatemala. ${ }^{20}$

INCO planned to build an open-pit nickel mine near the town of El Estor, located north of Lake Izabal in the department of Izabal in eastern Guatemala, not far from the United Fruit banana plantations. However, there were two immediate obstacles to the realization of INCO's objective. First, open-pit mining was prohibited under Guatemalan law. Second, the area around El Estor became the base of operations for guerrilla rebels. The mine would not be able to open unless "stability" was restored. ${ }^{21}$

INCO was able to get around these difficulties through negotiations with Guatemala's military government. INCO hired an engineer to write an INCO-friendly mining code, which was accepted by the Guatemalan Congress. ${ }^{22}$ The resulting mining code of April 1965 specifically allowed for "open sky mining". ${ }^{23}$ The company also received a 40-year lease to mine an area $385 \mathrm{~km}^{2}$ in size near El Estor as well as "generous tax concessions". Finally, the military government provided INCO with the understanding that it would guarantee "stability" in the region. ${ }^{24}$

15. Ibid at <http://shr.aaas.org/guatemala/ceh/report/english/conc2.html〉; Rigoberta Menchú, I, Rigoberta Menchú: An Indian Woman in Guatemala (London: Verso, 1994). In her book, Rigoberta Menchú recounts in detail the torture and murder of her brother and mother at the hands of the military. Menchú received the Nobel Peace Prize in 1992 for her advocacy of Indian rights in Guatemala and Western hemisphere.

16. At the time it was called International Nickel Company. It officially changed its name to INCO in 1976. See Peter McFarlane, "Inco and the Guatemalan Colonel," in Northern Shadows: Canadians and Central America (Toronto: Between the Lines, 1989) 122 at 123.

17. JH Bradbury, "International Movements and Crises in Resource Oriented Companies: The Case of Inco in the Nickel Sector" (1985) 61:2 Economic Geography 129 at 138.

18. Ibid.

19. McFarlane, supra note 16 at 124 .

20. Ibid.

21. Ibid at 125

22. Ibid at 127 .

23. Steven Driever, "The Role of Lateritic Nickel Mining in Latin American Countries with Special Reference to Exmibal in Guatemala" (1985) 11 GeoJournal 29 at 34.

24. McFarlane, supra, note 16 at 127. 
Colonel Carolos Arana Osorio was responsible for clearing the Indigenous people out of the INCO region in Zacapa-Lake Izabal. He launched what has been referred to as a "reign of terror" in the region, in which the number of people killed is estimated to be between three and six thousand. ${ }^{25}$ By 1967 he had been dubbed the "Butcher of Zacapa" ${ }^{26}$ According to J.H. Bradbury, peasants were removed from the mining area between 1968 and 1970 to allow for the development of the town and the mine site. ${ }^{27}$ At the same time, Canada showed ongoing support for the El Estor project, as the Canadian ambassador to Guatemala, S.F. Rae, went on a "wellpublicized tour of the mine site" in $1968 .^{28}$

There was strong opposition to the Exmibal project from Indigenous people and other concerned Guatemalans. A group of professors from the School of Economic Sciences at the University of San Carlos, Guatemala City, took up the cause and established a commission in 1969. ${ }^{29}$ The commission concluded that the Guatemalan government had not negotiated sufficient benefit from the project and that Exmibal would simply strip Guatemala of its riches. ${ }^{30}$

Public protests against the mine followed. President Arana ${ }^{31}$ responded by suspending the constitutional right to assembly and arresting large numbers of people. The army even occupied the university in its attempt to silence the opposition from the nation's intellectual community. State death squads assassinated two law professors and members of the commission, Julio Camey Herrera and Adolfo Mijangos López. ${ }^{32}$ One other member of the commission was wounded in an assassination attempt and another was forced to flee the country due to death threats. ${ }^{33}$ The UN Commission on Historical Clarification ("UN Commission”) later found that these crimes were committed because of opposition to the government's policies. ${ }^{34}$

In February 1971, an exploitation agreement was signed between INCO and the Guatemalan government. $^{35}$

25. Ibid.

26. Ibid at 128.

27. Bradbury, supra note 17 at 138.

28. McFarlane, supra note 16 at 129.

29. Ibid.

30. Driever, supra note 23 at 36 .

31. This is the same Arana who was responsible for the military sweep of the El Estor area in the late sixties. He was elected as president in 1970, in what was referred to as a "fraudulent election". Upon his election, Arana stated that he would, if necessary, "turn the country into a cemetery in order to pacify it". See McFarlane, note 14 at 130.

32. Ball, Kobrak \& Spirer, supra note 13 at 18; Bradbury, supra note 17 at 138.

33. Ball, Kobrak \& Spirer, ibid at 103-4.

34. CEH Report 1999, supra note 13, online: AAAS <http://shr.aaas.org/guatemala/ceh/gmds_pdf/anexo1_1.pdf〉 at 104.

35. Driever, supra note 23 at 34. 
Major construction began on the El Estor mine in $1974^{36}$ aided by a $\$ 20$ million loan from the Canadian Export Development Corporation. ${ }^{37}$ The UN Commission documented violence associated with the mine during this period. In 1978, two people in El Estor were shot and wounded by men riding in an Exmibal truck. ${ }^{38}$ The next month, employees of Exmibal were involved in the execution of four people in the municipality of Panzós, near El Estor. ${ }^{39}$ In 1981, police officers riding in an Exmibal truck killed community leader Pablo Bac Caal. ${ }^{40}$

In 1982, the market value of nickel was declining while the cost of oil was rising. As a result, INCO shut down the El Estor mine. ${ }^{41}$ While the mine lay dormant, violence in Guatemala continued. The most serious human rights violations were perpetrated under the dictator Rios Montt. There were 192 massacres in 1982 alone. $^{42}$ Despite condemning these human rights violations in Guatemala in 1983, the Canadian government was in negotiations to sell military planes to the Guatemalan air force. ${ }^{43}$ The Guatemalan military had been known to use their planes to shoot at Indigenous villages. ${ }^{44}$

In 1983, General Oscar Humberto Mejía Víctores overthrew Rios Montt and promoted the return of a democratic system in Guatemala. ${ }^{45}$ The first civilian president in 15 years was elected in 1985 . $^{46}$ However, the military still retained much of its power, and massacres of Indigenous villagers continued well into the $1990 \mathrm{~s} .{ }^{47}$ The military also silenced individual critics, among them, anthropologist Myrna Mack Chang. She had dedicated herself to identifying the remains of those killed during the civil war and exposing the military's role in those deaths. She was stabbed to death in $1990 .^{48}$

In 1996, the Guatemalan government signed a Peace Accord with the guerrillas, ending the 36-year civil war. For a moment, there was a promise of a significant transformation of

36. Driever, supra note 23 at 34

37. Stephen Lewis, "INCO Strike Leaves Bitter Legacy," Toronto Star (15 April 1979) A20.

38. CEH Report (1999), supra note 13, online: AAAS <http://shr.aaas.org/guatemala/ceh/gmds_pdf/anexo2_2.pdf> at 679.

39. Ibid, online: AAAS <http://shr.aaas.org/guatemala/ceh/gmds_pdf/anexo2_1.pdf> at 105.

40. Ibid, online: AAAS <http://shr.aaas.org/guatemala/ceh/gmds_pdf/anexo2_2.pdf> at 674.

41. Driever, supra note 23 at 34.

42. CEH Report (1999), supra note 13; Ball, supra note 13 at 21-22. For example, Oliverio Castañeda de León, a member of the University Student Association, was machine gunned to death in broad daylight in front of hundreds of witnesses including police. The police did not attempt to chase or arrest the shooters; Oficina de Derechos Humanos del Arzobispado de Guatemala ("ODHAG"), "Informe para la Recuperación de la Memoria Histórica: Nunca Más” (24 April 1998) at vol 4, ch 2, online: ODHAG <http://www.odhag.org.gt/INFREMHI/ Default.htm> ["Nunca Mas"].

43. Jonathan Lemco, "Canadian Foreign Policy Interests in Central America: Some Current Issues" (1986) 28:2 J. Interamerican Studies and World Affairs 119 at 123 .

44. Ibid.

45. Susanne Jonas, The Battle for Guatemala: Rebels, Death Squads, and US Power (Boulder: Westview Press, 1991 ) at 153.

46. Ibid. at 156 .

47. Monsignor Juan Gerardi, Proyecto Interdiocesano de Recuperación de la Memoria Histórica (REMHI), http://www.derechoshumanos.net/lesahumanidad/informes/guatemala/informeREMHI-Tomo1.htm (in Spanish only). Abridged versions in French and Spanish available at http://www.odhag.org.gt/html/Default.htm

48. "International court condemns Guatemala over murder," Reuters News (19 December 2003). 
Guatemalan society. Under the accords, the government would be compelled to take action on a wide range of subjects including agrarian reform and rural development; decentralization; social services, such as health, education, employment, and social security; reform of the administration system of justice; reform of the military and of the systems of intelligence of the state; electoral reform; recognition of the rights of women; and the integration of populations uprooted and demobilized during the civil war. ${ }^{49}$ Particularly significant was the Agreement on the Identity and Rights of Indigenous Peoples, which established political rights for Mayan people by redefining Guatemala as a multiethnic, multicultural, and multilingual nation. ${ }^{50}$ The section referring to economic rights focused on land, recognizing that Indigenous communities have "historically been the victims of land plundering" 51 and calling for the restitution of expropriated communal lands, the immediate titling of lands historically occupied by Mayan people, and a comprehensive program of land reform. ${ }^{52}$ Despite these commitments to recognize Mayan land ownership, Guatemala took steps to facilitate foreign investment in mineral resources. In 1997, in response to pressure from the World Bank, Guatemala decreased royalties to one percent of revenues and lifted restrictions on foreign ownership. ${ }^{53}$

Two studies were started to address the abuses committed during the war. In 1998, Monsignor Juan Gerardi released the results of evidence and testimony of 600 people collected from across Guatemala over three years. His report, Guatemala: Nunca Mas ("Never Again”) stated that over the course of the civil war, 150,000 people were murdered, 50,000 disappeared and one million had been displaced. ${ }^{54} \mathrm{He}$ put the blame for the overwhelming majority of atrocities on the Guatemalan military.

The United Nations Commission on Historical Clarification produced the second study. In its 1999 report, Guatemala: Memories of Silence, the UN Commission found that the state, in some capacity, was responsible for 93 per cent of the human rights violations that occurred

49. Luis Pásara “The Guatemalan Peace Process: The Accords and Their Accomplishments” Kroc Institute Occasional Paper (December 2001) at 12 .

50. Hilde Salvesen, "Guatemala: Five Years after the Peace Accords”, (Oslo: International Peace Research Institute, ("PRIO”), March 2002), online: PRIO <http://www.prio.no/files/file44990_guatemala_report_salvesen.pdf>.

51. "Accords of the Guatemalan Peace Process" at 49, online: Conciliation Resources <http://www.c-r.org/sites/cr.org/files/Accord\%2002_5Accords\%20of\%20the\%20Guatemalan\%20peace\%20process_1997_ENG.pdf>.

52. Rachel Sieder, "Reframing Citizenship: Indigenous Rights, Local Power and the Peace Process in Guatemala" (1997), online: Conciliation Resources <http://www.c-r.org/our-work/accord/guatemala/reframing-citizenship.php>.

53. Leonardo A Crippa, "Cross-cutting issues in the application of the Guatemalan "NEPA": Environmental impact assessment and the rights of indigenous peoples” (2008-2009) 24 Am U Int'1 Rev 103 at 133.

54. See supra note 52; Teo Ballve, "Remembering in the Land that Memory Forgot" NACLA News (14 May 2007), online: North America Congress on Latin America ("NACLA") <http://news.nacla.org/2007/05/14/remembering-in-the-land-that-memory-forgot/>. 
during the war" and that the state had "committed acts of genocide against groups of the Maya people." 56

\section{The Fenix ProJeCt}

In 2004, a Canadian company called Skye Resources purchased the mine at El Estor, which had been inoperative since 1982. At that time, the mine came to be known as "Fenix" and was to be operated by Skye's Guatemalan subsidiary Compañia Guatemalteca de Niquél ("CGN”). As INCO's original mining concession from the 1960s was set to expire, the Guatemalan government granted a licence for mining exploration at El Estor on December 13, $2004 .^{57}$ According to a committee of the International Labour Organization ("ILO"), the Guatemalan government breached its obligation under ILO Convention No. 169 to consult with the affected Indigenous people prior to granting the licence. ${ }^{58}$

In the same year, Canada's ambassador to Guatemala, James Lambert, was enthusiastically promoting Canadian mining in Guatemala. He discussed the benefits of Canadian mining on the Guatemalan talk show "El Libre Encuentro"59 and published an opinion piece in a Guatemalan newspaper in which he stated that Canadian mining companies are at the "vanguard of advanced technology, protection of the environment and social responsibility". 60

The Mayan Q'eqchi' farmers in the Izabal region were generally unaware that INCO had sold the mine and that nickel prices had gone up. They had been gradually returning to their traditional lands in El Estor and some had started land claims in the courts. ${ }^{61}$ Some new settlements were formed on these lands, including the community of Barrio Revolución, and

55. United Nations, "Report of the United Nations Verification Mission in Guatemala ("MINUGUA") for the Consultative Group meeting for Guatemala" (18 January 2002) at 2, online: Inter-American Development Bank <http://www.iadb.org/regions/re2/consultative _group/gu/minugua_eng.pdf $>$.

56. Ibid.

57. International Labour Organization (2007), Report of the Committee set up to examine the representation alleging non-observance by Guatemala of the Indigenous and Tribal Peoples Convention, 1989 (No. 169) at para 40, online: ILO <http://www.ilo.org/ilolex/cgilex/pdconv.pl?host=status01\&textbase $=$ iloeng \&document $=87 \&$ chapter $=16 \&$ query $=\% 28 \mathrm{C} 169 \% 29+\% 40$ ref $\&$ highlight $=\&$ querytype $=$ bool $\&$ context $=0$ >.

58. Ibid at 51 .

59. Libre Encuentro (video), January 23, 2005, online: World News: 〈http://wn.com/Libre_Encuentro_Jan_23,_2005_episode_>.

60. James Lambert, "Colaboración: Minería en Canadá: Como Guatemala, Canadá es reconocido en el mundo entero por la riqueza de sus recursos naturales" Prensa Libre (04 November 2004), online: Schnoor v Canada <http://www.schnoorversuscanada.ca/docs/prensa-librejames-lambert.pdf>.

61. Canadian Broadcasting Corporation [CBC], "Unfinished Business" Sunday Edition, Hour Three (25 September 2011) at 13:30, online: CBC $<$ http://www.cbc.ca/video/player.html?clipid=2141604355\&position=990702\&site=cbc.news.ca > [CBC, "Unfinished Business"]. 
other communities, such as La Unión were reoccupied. ${ }^{62}$ According to HudBay, the subsequent owner of the mine, not everyone who settled in El Estor at this time had previously lived there. ${ }^{63}$

Skye Resources referred to the reoccupation of the El Estor region as "land invasions" 64 despite the fact that many of the inhabitants had historically lived on the land before they were forced out in the 1960s and 1970s by Guatemala's military dictatorship. Because of Skye Resources' belief that it had the exclusive right to occupy the area, court orders were obtained in order to remove the "squatters". 65 On January 8 and 9 of 2007, hundreds of armed police officers and members of the military conducted forced evictions of at least five communities in the El Estor region, including Barrio Unión, La Pista, Barrio Revolución, Barrio La Paz, and Lote Ocho. ${ }^{66}$ During the evictions, people's homes were destroyed and some were burned. ${ }^{67}$

Steven Schnoor, a Ph.D. student at York University was in El Estor during the evictions and caught the events on film. His film shows people refusing to leave their land in Barrio Unión after being read an eviction notice by the public prosecutor. One woman is shown protesting, "We are the owners of this land...Where are we going to go now?" The eviction in Barrio Revolución was apparently less civil. According to one report, riot police surrounded community members who were gathered together while CGN employees burned their homes. ${ }^{68}$

According to Skye Resources, "a peaceful atmosphere" was maintained during the evictions. ${ }^{69}$ President and CEO Ian Austin admitted that homes were burned, but claimed that the burning of homes was not caused by company people. ${ }^{70}$ In a press release issued on January $10^{\text {th }}$, Austin thanked the Guatemalan police for the "professional manner in which this unfortunate situation was resolved". 71 He stated that the company remains committed to "continue [its] discussions on matters of concern with the local communities in the El Estor region."

62. Dawn Paley, "This is what development looks like" (11 January 2007), online: The Dominion <http://www.dominionpaper.ca/articles/900>.

63. HudBay Minerals, "The facts: HudBay's former operations in Guatemala", online: HudBay <http://www.hudbayminerals.com/English/Responsibility/CSR-Issues/The-facts-Hudbays-former-operations-in-Guatemala/default.aspx> [HudBay, "The Facts"].

64. Skye Resources, "Land Occupations End at Fenix Project" (10 January 2007) online: Schnoor v Canada 〈http://www.schnoorversuscanada.ca/docs/skye-pr.pdf>.

65. Note that the first evictions in November took place without a court order, which is required by Guatemalan law: Paley, supra note 62.

66. See Skye Resources, supra, note 64 and Paley, ibid for two very different accounts of the evictions. The first four communities are listed in Paley. Lote Ocho is listed in Caal v. HudBay, Amended Statement of Claim filed March 28, 2011, online: <http://www.chocversushudbay.com/legal-documents> at para 57 [Caal Statement of Claim].

67. Paley, ibid. See also Klippensteins, "Canadian Mining in El Estor", online: <http://www.chocversushudbay.com/history-of-the-mine>.

68. Paley, ibid.

69. Skye Resources, supra note 64.

70. CBC, As It Happens (19 March 2007), online: Rights Action <http://www.rightsaction.org/video/elestor/CBC_AsItHappens_IanAustin_March192007.mp3> at 2:48.

71. Skye Resources, supra note 64. 
After Schnoor posted his video of the forced evictions on Youtube, the Canadian Ambassador to Guatemala, Kenneth Cook, attempted to discredit it. Cook claimed that Schnoor had hired an actor to play the part of a woman being evicted, and that still photographs in the documentary showing homes being burned and a man holding his head in despair were actually taken many years earlier during the civil war. ${ }^{72}$ Schnoor sued the Ambassador for slander in Ontario Small Claims Court, and the judge ruled in Schnoor's favour, stating that the Ambassador was "careless" and that "he should have known better." 73 Schnoor was awarded about $\$ 10,000$ for damages and costs.

After being evicted from El Estor, the Mayans fled into the mountains. However, a few days later, they returned to the land and began to rebuild their homes, only to be forced out of their homes again on January $17^{\text {th }}{ }^{74}$ During these evictions, eleven Mayan women of Lote Ocho were allegedly gang-raped by police, military, and Fenix security personnel. ${ }^{75}$ The women were allegedly trapped by security personnel as they were attempting to leave their homes, and then violently raped by groups of men, including members of the Fenix security team who were wearing uniforms bearing the initials "CGN". ${ }^{76}$ Two of the women were pregnant at the time of the alleged rapes, and subsequently lost their unborn children. One is no longer able to have children. ${ }^{77}$

CGN denies that these rapes occurred. According to the company, police reports show that no "illegal occupiers" were even present at the evictions on the date of the alleged rapes. ${ }^{78}$ The company claims that the evictions were carried out peacefully and that no CGN personnel were involved in implementing them. ${ }^{79}$

The Fenix mine changed ownership again in 2008, when HudBay Minerals purchased Skye Resources. ${ }^{80}$ HudBay announced that it did not plan to begin construction at the Fenix site until market conditions became more favourable. ${ }^{81}$ During this time, some of the Mayan

\footnotetext{
72. Schnoor v Canada, [2010] OJ No 6135 (QL) at para 87.

73. Ibid at para 122 .

74. CBC, "Unfinished Business", supra note 61 at 14:30.

75. Caal Statement of Claim, supra note 66.

76. Ibid at para 63-64.

77. Ibid at para 65-67.

78. HudBay, "The Facts", supra note 63.

79. Ibid.

80. HudBay Minerals, Inc, "Hudbay Minerals Completes Business Combination With Skye Resources; Announces New Director and Chief Financial Officer" (26 August 2008) online: HudBay Minerals <http://www.hudbayminerals.com/default.aspx?SectionId=5cc5ecae-6c484521-a1ad-480e593e4835\&LanguageId=1\&PressReleaseId=c0e9ae5e-c314-4898-8008-137ec8d9c764>.

81. HudBay Minerals, Inc., "Hudbay reports third quarter results" (04 November 2008) online: HudBay Minerals <http://www.hudbayminerals.com/English/Media-Centre/News-Releases/News-Release-Details/2008/HudBay-Reports-Third-QuarterResults/default.aspx>.
} 
Q'eqchi' people returned once again to their ancestral land. Canadian Ambassador Cook referred to these people as 'invaders ${ }^{, 82}$ and 'squatters' ${ }^{83}$; HudBay referred to them 'illegal occupiers'. ${ }^{84}$

In 2009, nickel was rising in price, and the company began considering spending the $\$ 1$ billion necessary to open the mine. ${ }^{85}$ Meanwhile, local Indigenous people continued their opposition. On September 27, 2009, there were community protests against mining activities in several communities located near the Fenix mine, including in the communities of La Unión and Las Nubes. Violence erupted that day resulting seven people being shot, the death of community leader and school teacher, Adolfo Ich Chamón, and serious injury to another community member, German Chub Choc. Five security guards were reportedly injured. ${ }^{86}$ The series of events that led up to the violence are in dispute, and are the subject of two law suits currently making their way through the Canadian court system.

According to one version of events, the governor of Izabal along with fifty CGN security guards entered the community of Las Nubes in order to discuss resettlement of the community. ${ }^{87}$ These discussions lasted for a few hours, but did not lead to an agreement. In response to CGN's presence, community members organized protests in order to assert their right to remain on their ancestral land. Adolfo Ich's family claims that protests were sparked by the "intrusion of Fenix security personnel into Mayan Q'eqchi' communities" and "fears of renewed forced and violent evictions". ${ }^{88}$ Residents of La Unión joined those of Las Nubes in a march toward the town of El Estor to denounce "illegal evictions" and to gather support for their cause. ${ }^{89}$ At around three in the afternoon, security guards reportedly opened fire on community members, wounding eight people. $^{90}$ According to the Ich family's statement of claim, Adolfo Ich was in his home in La Unión when he heard gunshots being fired. He left his home in order to see what was going on

\footnotetext{
82. E-mail from Kenneth Cook, (21 January 2008) "Protected A Skye resources CGN - mission critical. Follow up", online: Schnoor v Canada <http://www.schnoorversuscanada.ca/docs/cook-email-re-skye.pdf>.

83. "Protected A - privileged communications with a Cdn company and the Guatemalan government", online: Schnoor v Canada $<$ http://www.schnoorversuscanada.ca/docs/embassy-meeting-re-skye.pdf $>$.

84. HudBay, "The Facts", supra note 63.

85. Sarah Grainger, "Land dispute threatens major Guatemala nickel project", Reuters (12 October 2009) online: Reuters <http://www.reuters.com/article/idUSN1254892220091012>.

86. Ibid.

87. Susan Fitzpatrick Behrens, "Nickel for Your Life: Q'eqchi' Communities Take On Mining Companies in Guatemala" North American Congress on Latin America, (25 October 2009) online: North American Congress on Latin America <https://nacla.org/node/6177>.

88. Choc v HudBay, Second Amended Fresh as Amended Statement of Claim (24 September 2010) at para 51 [Choc Statement of Claim].

89. James Rodriguez, "Barrio La Union Leader Killed by CGN's Security Agents in El Estor" (29 September 2009), online: MiMundo <http://www.mimundo.org/2009/09/29/barrio-la-union-leader-killed-by-cgn\%E2\%80\%99s-security-agents-in-el-estor/>.

90. Behrens, supra note 87.
} 
and to see if he could help "restore the calm" " As he was a respected community leader, he was apparently recognized by security personnel. The claim states that he was unarmed when he was surrounded by a dozen armed CGN security guards who beat him, dragged him away, and severed his arm with a machete. The head of CGN security, Mynor Padilla, is then alleged to have shot him in the head. Padilla is a former high-ranking officer in the Guatemalan military. ${ }^{92}$

HudBay provided a strikingly different version of events. According to the company, authorities were attempting to "peacefully resolv[e] illegal occupations through dialogue" when "organized protestors" attacked departing government vehicles. ${ }^{93}$ HudBay claims that the protestors stole automatic firearms and other weapons from the police station and attacked a community hospital, which had been sponsored by CGN. ${ }^{94}$ HudBay acknowledged that a protestor died that day; however, it claims that "CGN personnel were not involved with his death". 95 HudBay suggested that Ich died as a result of a "confrontation among the protestors". 96 The company stated that they "deeply regret" the loss of life that occurred and reaffirmed that their number one priority is the "safety and security of all residents and employees in El Estor". 97 It further asserted that private security personnel "showed great restraint and acted only in self defence". 98 The company claims to be committed to working with residents to arrive at a "fair and equitable solution to the land claims and resettlement". ${ }^{99}$ Regardless of which version of events is believed, the incident highlights the ongoing tensions occurring in the area as a result of unsettled land claims.

Employees of HudBay continued to maintain that the land belonged to HudBay and that Mayan presence on the land is the result of a series of "invasions". ${ }^{100}$ A CGN community relations man defended HudBay's claim to the land in a Canadian Broadcasting Company television documentary, stating, "It's our land and they took it...Guatemala ha[s] law, like Canadians, like U.S. People need to respect the law."

91. Choc Statement of Claim, supra note 88 at paras 53-54.

92. Ibid at paras 55-59.

93. HudBay Minerals Inc., "HudBay Minerals Provides Update on CGN", 29 September 2009, online: <http://www.hudbayminerals.com/English/Media-Centre/News-Releases/News-Release-Details/2009/HudBay-Minerals-Provides-Updateon CGN/default.aspx>. [HudBay, "Update on CGN"].

94. Ibid.

95. HudBay, "The Facts", supra note 63.

96. HudBay, "Update on CGN", supra note 93.

97. Ibid.

98. Ibid.

99. Ibid.

100. CBC, "Unfinished Business", supra note 61 at 17:30.

101. Ibid at 17:30 - 18:05. 
In September 2011, HudBay sold the Fenix mine and all of its Guatemalan assets to Solway Investment Group, a private company with a head office in Cyprus. ${ }^{102}$ While HudBay had purchased the mine for $\$ 446$ million, it was sold for only $\$ 176$ million. ${ }^{103}$ The lawsuits against HudBay will continue despite the sale, and will be discussed in more detail in the following section ${ }^{104}$

\section{The Corporate Social ReSPONSIbILITy LaNdSCAPE IN CANADa}

The Canadian mining industry, government and non-government organizations have made attempts to address widespread concerns about human rights abuses associated with the extractive industries. In 2006, the Government of Canada held four National Roundtables on Corporate Social Responsibility and the Canadian Extractive Sector in Developing Countries (the "National Roundtables") in response to a report by the Canadian Parliament's Standing Committee on Foreign Affairs and International Trade. This Committee had called for the implementation of a multi-stakeholder process dedicated to the creation and strengthening of programs and policies with regard to mining and corporate social responsibility ("CSR") in developing countries. ${ }^{105}$

The Advisory Group to the National Roundtables released a comprehensive report ("the Advisory Report"), ${ }^{106}$ which made a series of recommendations to improve the CSR practices of Canadian extractive companies operating in developing nations. ${ }^{107}$ One of the main recommendations was to develop a Canadian CSR framework, including instituting an ombudsman who would act in an advisory and fact-finding capacity in relation to complaints about the operations of Canadian extractive companies overseas. ${ }^{108}$ The Canadian government would withdraw support and investments from its Canada Pension Plan, when companies were found to be in violation of the appropriate standards.

102. HudBay Minerals Inc., "HudBay Minerals Announces Completion of Sale of Fenix Project and Key Management Appointments" (09 September 2011), online: <http://www.hudbayminerals.com/default.aspx?SectionId=5cc5ecae-6c48-4521-a1ad-

480e593e4835\&LanguageId=1\&PressReleaseId=c4c56f9d-8be7-4600-898f-3b07f7aa8eac $>$. For more information on Solway and the Fenix mine, see "Fenix Nickel Project, Guatemala", online: Solway Group < http://www.solway.ru/itemf_16.htm $>$. It is interesting to note that the description of the Fenix project does not make any mention of the social unrest related to the mine.

103. CBC, "Unfinished Business", supra note 61 at 29:55.

104. Klippensteins, supra note 67.

105. See Standing Committee on Foreign Affairs and International Trade (SCFAIT), Fourteenth Report: Mining in Developing CountriesCorporate Social Responsibility, 38th Parliament, 1st Session, June 2005, 2, online: <http://cmte.parl.gc.ca/cmte/CommitteePublication.aspx?COM=8979\&Lang=1\&SourceId=178650>.

106. National Roundtables on Corporate Social Responsibility (CSR) and the Canadian Extractive Industry in Developing Countries, "Advisory Group Report", (29 March 2007), online: <http://www.international.gc.ca/trade-agreements-accords-commerciaux/ds/csr.aspx>

107. Ibid. The Advisory Group "included representatives from industry associations; individuals currently or formerly employed by extractivesector companies active overseas; civil society organisations; labour; academics; and the responsible investment sector".

$108 \mathrm{Ibid}$ at 23 . 
In 2009, the federal government responded with a policy called "Building the Canadian Advantage: A CSR Strategy for the International Extractive Sector", which provided token support for enhancing CSR guidelines and created an Office of the Extractive Sector Corporate Social Responsibility Counsellor. ${ }^{109}$ This initiative fell well short of the recommendations of the National Roundtables. The Counsellor can only act when there has been a complaint; a process can be instituted only with the agreement of the corporation; it cannot offer determinations as to whether harm has occurred; it cannot investigate the complaints; and it cannot issue binding recommendations on the corporations. ${ }^{110}$ The limitations of the process are clearly illustrated in a complaint that was lodged against a Canadian mining company, Excellon Resources Inc., in Mexico for its labour practices. The Counsellor found that the Mexican workers were "eager to engage in a good faith dialogue", but Excellon's refusal to participate ended the process ${ }^{111}$

In order to provide a better accountability mechanism, on February 9, 2009, Liberal M.P. John McKay introduced Bill C-300, An Act respecting Corporate Accountability for the Activities of Mining, Oil or Gas in Developing Countries. ${ }^{112}$ The Bill provided that the government would establish corporate accountability standards for Canadian extractive companies, ${ }^{113}$ create a mechanism through which complaints against a Canadian extractive corporation could be made, and would withhold public funding from corporations which breached the accountability standards, by divesting shares held by the Canada Pension Plan or rendering companies ineligible for funding or guarantees of loans by Export Development Canada. $^{114}$ Bill C-300 was supported by many non-governmental organizations including Amnesty International, Mining Watch Canada, Ecojustice Canada, and World Vision, ${ }^{115}$ but was severely criticized by industry representatives who argued that it would reduce Canada's

109. Foreign Affairs and International Trade Canada, "Building the Canadian Advantage: A Corporate Social Responsibility (CSR) Strategy for the Canadian International Extractive Sector" (March 2009) online: <http://www.international.gc.ca/trade-agreements-accordscommerciaux/ds/csr-strategy-rse-stategie.aspx>.

110. Office of the Extractive Sector Corporate Social Responsibility Counsellor, "About us", online: Foreign Affairs and International Trade Canada 〈http://www.international.gc.ca/csr_counsellor-conseiller_rse/About_us-A_propos_du_bureau.aspx $>$. For a further analysis, see: Mining Watch, "Concerns with regard to the mandate and review procedure of the Office of the Corporate Social Responsibility Counsellor for the Government of Canada" (March 2011), online: Mining Watch <http://www.miningwatch.ca/article/concerns-regard-mandate-andreview-procedure-office-corporate-social-responsibility>.

111. Office of the Extractive Sector Corporate Socially Responsibility Counsellor, "Closing report: Request for review file \#2011-01-MEX" (October 2011), online: Foreign Affairs and International Trade Canada <http://www.international.gc.ca/csr_counsellorconseiller_rse/assets/pdfs/Closing_report_MEX.pdf>.

112. Bill C-300, An Act respecting Corporate Accountability for the Activities of Mining, Oil or Gas in Developing Countries, 2nd Sess, 40th Parl, 2009, online: <http://www2.parl.gc.ca/HousePublications/Publication.aspx?Docid=3658424\&file=4>.

113. Ibid, $\mathrm{s} 5$.

114. Ibid, ss 4,8 and 10 .

115. John McKay, "Supporters of C-300", 26 October 2009, online: 〈http://www.johnmckaymp.on.ca/newsshow.asp?int_id=80590>. 
competitiveness in the global mining industry. ${ }^{116}$ On October 28, 2010, Parliament rejected Bill C-300, by a narrow margin of six votes. ${ }^{117}$

The failure of government to legislate to ensure that mining corporations are held accountable for their actions overseas has left a gap in the corporate accountability framework.

\section{The Courts In CANAda}

Judges in Canada have had several occasions to address concerns with the activities of mining companies. Unfortunately, with only one exception, judges have refused to hear any of the cases on their merits. They have relied on three main reasons. The first reason is based on jurisdiction. A court will not allow a lawsuit to proceed if it feels that it is not substantially connected to Canada. The second reason is forum non conveniens. A court in Canada could decide that another country provides a more appropriate forum. The third principle is duty of care. Unless there is a sufficiently close relationship between a Canadian individual or institution and the victims of abuse overseas, those in Canada do not have to accept responsibility for what happens at their mines overseas.

\section{(i) Jurisdiction}

On November 8, 2010, the Canadian Association Against Impunity brought a class action against Anvil Mining Ltd. in Quebec for the corporation's actions relating to a massacre in the Democratic Republic of the Congo ("DRC"). ${ }^{118}$ Anvil Mining was headquartered in Perth, Australia but opened a small office in Montreal on June 1, 2005. ${ }^{119}$ Its primary activity was the exploration of a mine located 55 kilometres from Kilwa in the DRC.

On October 13, 2004, a small group of approximately ten armed individuals from neighboring Zambia claiming to act on behalf of the Revolutionary Movement for the Liberation

116. Les Whittington, "Mining companies deny abuses", Toronto Star (27 November, 2009) online: <http://www.thestar.com/news/canada/article/731559--mining-companies-deny-abuses>.

117. Bill C-323, An Act to amend the Federal Courts Act (international promotion and protection of human rights), 1st Sess, 41st Parl, 2011, online: $\langle$ http://www.parl.gc.ca/LegisInfo/BillDetails.aspx?billId=5138027\&Mode=1\&Language=E $>$.

118. "Class Action Filed Against Anvil Mining by Congolese Victims" (16 November, 2010), online: Mining Watch <http://www.miningwatch.ca/article/class-action-filed-against-anvil-mining-congolese-victims>.

119. Association canadienne contre l'impunité (ACCI) c Anvil Mining Ltd. (2011), 2011 QCCS 1966 (CanLII), online: <http://www.canlii.org/fr/qc/qccs/doc/2011/2011qccs1966/2011qccs1966.html> [Anvil Mining: Superior Court] See also, United Nations Organization Mission in the Democratic Republic of Congo, "Report on the conclusions of the Special Investigation into allegations of summary executions and other violations of human rights committed by the FARDC in Kilwa (Province of Katanga) on 15 October 2004" at para 3, online: <http://www.abc.net.au/4corners/content/2005/MONUC_report_oct05.pdf > ["MONUC Report"] which states that contrary to rumors, there were no Zambian citizens implicated in the insurrection. 
of Katanga, entered Kilwa. ${ }^{120}$ The Government of the DRC ordered army officers to remove the men and to regain control of Kilwa. Later in 2004, the UN Mission in the DRC conducted a verification mission and reported on the events, documenting the army's human rights violations against the people of Kilwa perpetrated during the counterattack. ${ }^{121}$ According to the Mission report, 73 civilians were killed and a large percentage of the population had been displaced, fleeing the counterattack. ${ }^{122}$ Twenty-eight people were reported to have been summarily executed based on suspicions that they supported the insurgents. ${ }^{123}$ Eyewitnesses reported that one of these victims, a 15-year-old student, "was shot by soldiers who wanted to steal his bicycle and his possessions." 124 The Mission also saw mass graves, hearing reports that twelve men were taken to a nearby area by soldiers, forced to kneel on the edge of the grave and were killed one by one. ${ }^{125}$ A large number of shopkeepers have confirmed that soldiers looted their stock and extorted money and goods from civilians in exchange for their freedom and safety. ${ }^{126}$

The Mission report stated that Anvil provided support to the military during the events by using its planes to transport troops to Kilwa, and by providing trucks, drivers, fuel, and food rations to the army. ${ }^{127}$ It stated that the managing director of Anvil Mining admitted in an interview with an Australian television station that the corporation provided logistics to the army and that the corporation has strong links with Katumba Mwanke, a close adviser of the President of the DRC, Joseph Kabila. ${ }^{128}$ Although the corporation claimed that it was required to comply with army's request, representatives of the mine denied the Mission's request to obtain information from employees requisitioned by the army. ${ }^{129}$

In 2007, seven soldiers and three officers of Anvil were tried before a military court. Two soldiers were found guilty of murder, while the others were acquitted. The victims did not receive compensation. On appeal, the two soldiers received reduced sentences and were later reintegrated into the army. ${ }^{130}$ That same year, a class action was instituted in Australia on behalf of the victims. The lawyers in the Australian proceeding withdrew after the NGO partner on the

120. Ibid. See also, MONUC Report, ibid at 1.

121. MONUC Report, ibid at 1.

122. Ibid.

123. Ibid at 6 .

124. Ibid.

125. Ibid at 7.

126. Ibid at 8 .

127. Anvil Mining: Superior Court, supra note 119.

128. MONUC Report, supra note 119 at 9.

129. Ibid at 10.

130. Anvil Mining Ltd. c. Association canadienne contre l'impunité, 2012 QCCA 117 (CanLII) at paras 27 to 31 [Anvil Mining: Court of Appeal], online: <http://canlii.ca/t/fpr75> CAAI has sought leave to appeal to the Supreme Court of Canada. 
ground could not obtain supporting affidavits due to severe intimidation and threats by members of the DRC government. The plaintiffs have not been able to find another lawyer in Australia to represent them. ${ }^{131}$

At the trial level, the Quebec Superior Court found that it had jurisdiction to hear the case, holding that if the Court were to refuse to accept the application, there would be no better jurisdiction in which the victims' civil claim could be heard, ${ }^{132}$ rejecting the argument that the DRC or Australia provided more appropriate forums. The trial judge found that as the mine in the DRC was Anvil's chief mine, the work in Quebec was therefore necessarily related to the operations in the DRC.

However, the Quebec Court of Appeal overturned the trial judge's decision and dismissed the action on the basis that the Court had no jurisdiction. ${ }^{133}$ It found that at the time of the massacre, there was no activity or office in Quebec, and that, in any event, the dispute was not substantially connected to Anvil's work in Quebec. ${ }^{134}$ The judge found that the claim against Anvil could be heard in Australia, as the corporation was headquartered there and that victims could bring their case before the courts in the DRC, despite the fact that attempts had been made to try the cases in those jurisdictions before. ${ }^{135}$

\section{(ii) Forum Non Conveniens}

Even where a court accepts jurisdiction, the defendant company can assert that there is a more appropriate forum where the claim can be heard. In 1998, a class action was brought in Quebec against Canadian mining corporation, Cambior Inc., by a group of 23,000 victims represented by a public interest group, Recherches Internationales Québec. The action was in respect of a failed tailings dam leaking 2.3 billion litres of liquid containing cyanide and heavy

131. Anvil Mining: Superior Court, supra note 119 at para 34.

132. Ibid at para 39.

133. Anvil Mining: Court of Appeal, supra note 130. This decision was based on Article 3148 of the Quebec Civil Code, SQ 1991, c 64. The Supreme Court of Canada has recently revised the common law test for establishing jurisdiction in Club Resorts Ltd. v. Van Breda, 2012 SCC 17 (CanLII), online: http://canlii.ca/t/fqzt4 [Van Breda]. The Court determined that the party asking the court to assume jurisdiction may establish a presumption of real and substantial connection by showing that any of the following factors are present: (a) the defendant is domiciled or resident in the province; (b) the defendant conducts on business in the province; (c) the tort was committed in the province; and (d)a contract connected with the dispute was made in the province (paragraph 90).

134. Ibid at para 103.

135. Ibid at paras 99-102. The Supreme Court of Canada refused to grant leave to appeal. 
metals on August 19, 1995. ${ }^{136}$ The resulting contamination of the Esequibo River led Justice Maughan who was hearing the case to describe it as one of the worst environmental disasters in gold mining history. ${ }^{137}$ The claim alleged that the spill resulted in the cyanide contamination of the aquatic wildlife on which the residents subsisted, affected their transportation routes and despoiled their source of water for drinking and bathing. ${ }^{138}$

The action was dismissed without being heard on the merits. The Quebec Superior Court ruled that it had jurisdiction but applied the legal doctrine of forum non conveniens codified in the Quebec Civil Code, under which courts may refuse to take jurisdiction where there is a more appropriate forum available to the parties. ${ }^{139}$ The Court found that Guyana rather than Quebec would be the more appropriate forum. ${ }^{140}$

The Court based its decision on the fact that Guyana was the location of the spill, the location of many of the witnesses and victims, the location where the damage was suffered and that Guyanese law would apply to the incident. ${ }^{141}$ Further, the Court noted that its decision not to hear the case did not deny the victims justice, since "Guyana's judicial system would provide the victims with a fair and impartial hearing", rejecting the claim that "the administration of justice is in such a state of disarray that it would constitute an injustice to the victims to have their case litigated in Guyana". ${ }^{142}$ The victims did pursue their claim in the Guyana courts, but due to failure to file an affidavit, the action was struck by the High Court of the Supreme Court of Judicature of Guyana in 2006 and the plaintiffs were ordered to pay the company's legal costs. ${ }^{143}$

In order to address problems of jurisdiction that arise when a corporation is incorporated in one jurisdiction and conducts operations in another (an issue with most multinational corporations), the European Union has removed the need to determine whether there is a connection between the forum and the claim or whether there is a more appropriate forum to

136. Recherches Internationales Québec v Cambior inc. [1998] Q.J.No. 2554 (SC) at paras 1-2 [Cambior].

137. Ibid at para 1.

138. Ibid at para 52.

139. This case was decided under the Civil Code of Quebec, SQ 1991, c 64, article 3135 . The Supreme Court of Canada in Van Breda, supra, note 133 at paragraph 110, listed several factors that may be considered in determining the most appropriate forum for the action, including "the locations of parties and witnesses, the cost of transferring the case to another jurisdiction or of declining the stay, the impact of a transfer on the conduct of the litigation or on related or parallel proceedings, the possibility of conflicting judgments, problems related to the recognition and enforcement of judgments, and the relative strengths of the connections of the two parties." Further, the Supreme Court has also stated in that the forum non conveniens analysis does not require that all these factors point to a single forum, but it does require that one forum ultimately emerge as clearly more appropriate. See Breeden v. Black, 2012 SCC 19.

140. Cambior, supra note 136 at para 9.

141. Ibid.

142. Ibid at para 12.

143. "Cambior Inc: Omai Lawsuit Struck and Dismissed" CNN Money, (31 October, 2006) online: <http://money.cnn.com/news/newsfeeds/articles/marketwire/06178759.htm〉. 
adjudicate corporate human rights abuses, providing that courts have jurisdiction where a defendant business is domiciled within their jurisdiction, or if the harm occurred there. ${ }^{144}$

For example, legal proceedings by 33 Peruvians were brought against UK-based Monterrico Metals PLC, for alleged torture by the Peruvian police in response to their protest against Monterrico's Rio Blanco copper mine in July 2005. ${ }^{145}$ The claimants had been separated from the main group of protestors when the police accompanied by Rio Blanco employees dispersed them with tear gas. The claimants were then captured and brought to a tarmac platform on which cattle were slaughtered. They were detained for two days, tortured and subjected to inhumane and degrading punishment including beatings, sleep deprivation, threats, rubbing salt into open wounds and in the case of the two females detained, sexual abuse. ${ }^{146}$ After the detainees were released (some into police custody), the claim alleged that police officers involved in suppressing the protest and conducting torture attended the Rio Blanco offices for payment. ${ }^{147}$ These events received renewed attention when videos were leaked to the press a few years later.

The plaintiffs claimed that Monterrico participated in their treatment by instigating, facilitating, directing or controlling the torture and failing to take adequate steps to minimize the torture that the plaintiffs experienced. ${ }^{148}$ The claim alleged that the police were in constant communication with mine officials who instructed them to destroy the protestors. ${ }^{149}$ Although Monterrico moved its corporate headquarters to Hong Kong, the plaintiffs were still able to commence the claim in England, as at the time that the harm occurred, the mining company was domiciled in England. The claimants also obtained a worldwide freezing injunction over $£ 5$ million of Monterrico's assets in order to prevent a judgment in London from being futile. ${ }^{150}$ The proceedings have been settled by compensation payments, although the corporation refuses to admit liability.

144. Council Regulation (EC) No 44/2001 of 22 December 2000 on jurisdiction and the recognition and enforcement of judgments in civil and commercial matters, Articles 2 and 5, Official Journal L 012, 16/01/2001 P. $0001-0023$.

145. Guerrero v. Monterrico Metals PLC, High Court of Justice, Queen's Bench, Claim Number HQ09X02331, Fourth Amended Particulars of Claim dated December 20, 2010.

146. Ibid at para 43.

147. Ibid at para 50, 51 and 59(C).

148. Ibid at para 3.

149. Ibid at para 42 .

150. "Peruvian torture victims obtain worldwide freezing injunction over mining company assets" (19 October 2009), Leigh, Day \& Co, Solicitors, online: http://www.leighday.co.uk/News/2009/October-2009/Peruvian-torture-victims-obtain-worldwide-freezing. 


\section{(iii) Duty of Care}

A component of establishing that a mining company is responsible for human rights abuses is the existence of a legal obligation to take reasonable care in the conduct of mining operations that could foreseeably harm the interests of the claimants. In Canada and in many other common law jurisdictions, duty of care is established when the court determines that (1) the harm suffered is "reasonably foreseeable" as a result of the defendant's conduct; and (2) there is a relationship of "proximity" between the defendant and the claimant, such that the defendant should be required to contemplate the claimant's legitimate interests when acting. ${ }^{151}$

In the context of transnational corporations, finding such a relationship is fraught with problems. Owing to legal requirements of the country where the mining is taking place or in order to avoid financial liability, a subsidiary of the parent corporation is often incorporated in the country of operations to conduct the extraction or production of the mineral resource. The subsidiary is in charge of day-to-day operations on the ground, which often include hiring and training employees, conducting exploration, and maintaining the mine. In addition, where third parties, such as private security companies hired by subsidiary corporations, commit violence against the community, it may be difficult to impute their wrongdoing to the parent corporation. Any liability for actions taken by employees on the ground must be imputed to the employer by the doctrine of vicarious liability.

However, suing the subsidiary may not effect the necessary change in the parent company's practices. The subsidiary may not be sufficiently capitalized to compensate the community. Further, as discussed in the jurisdiction section above, if the claimants do not have the opportunity to obtain a fair trial in their home jurisdiction, justice may be best served by having the case tried in a jurisdiction where there are more procedural protections in place.

The difficulty in establishing duty of care was evidenced by the suit commenced in 2008 against two of the directors of Copper Mesa, a Canadian mining company in Ecuador, as well as the Toronto Stock Exchange (TSX). ${ }^{152}$ The claimants, Ecuadorian campesinos from areas adjacent to Junin, where Copper Mesa attempted to carry out exploration activities, opposed the proposed mine. ${ }^{153}$

151. Donoghue v Stevenson, [1932] UKHL 100.

152. Piedra v Copper Mesa Mining Corporation: Statement of Claim, filed March 3, 2009, online:

<http://www.ramirezversuscoppermesa.com/>.

153. Ibid at paras 13 to 15 . 
The members of the community of Junin and the surrounding area were aware that if the corporation was listed on the TSX, the corporation would be able to raise money to suppress any opposition to the mine. ${ }^{154}$ Prior to Copper Mesa being listed, the mayor of the county in which Junin is located informed the TSX of the opposition to the mine in the community and the likelihood of violence, which was widely reported. ${ }^{155}$

The claim alleged that on or around December 2, 2006, a large group of armed members of security forces confronted members of the Junin community and without any provocation sprayed pepper spray directly into the eyes of one of the claimants. ${ }^{156}$ The security forces then shot wildly into the crowd injuring another of the claimants. ${ }^{157}$ A representative of the community met with the defendant directors on April 27, 2007 to advise them of the confrontation and risk of violence. ${ }^{158}$ However, the violence continued. One of the plaintiffs was alleged to have received death threats in June 2007 and one month later was allegedly attacked by a mob led by affiliates of the corporation, who assaulted him with sticks and rocks before the police intervened. $^{159}$

The allegations against the TSX and two company directors centered on raising funds in Canada that were then to be used to pay private security forces. ${ }^{160}$ In particular, the plaintiffs alleged that the TSX was negligent to list a corporation where there was a reasonably foreseeable risk that, without precautionary measures, funds raised on the TSX would be used in such a way as to harm individuals such as the plaintiffs. ${ }^{161}$ The claim alleged that the directors were personally liable for operating the corporation in such a way as to create high risk and failing to supervise corporate management and implement corporate policies. ${ }^{162}$

The Ontario motions judge struck out the claim, finding that there was no relationship between the plaintiffs and the TSX defendants to "have imposed an obligation on the TSX defendants to be mindful of the plaintiffs' interests when conducting their affairs." 163 Further, the judge found that the TSX defendants could not have foreseen the political and business

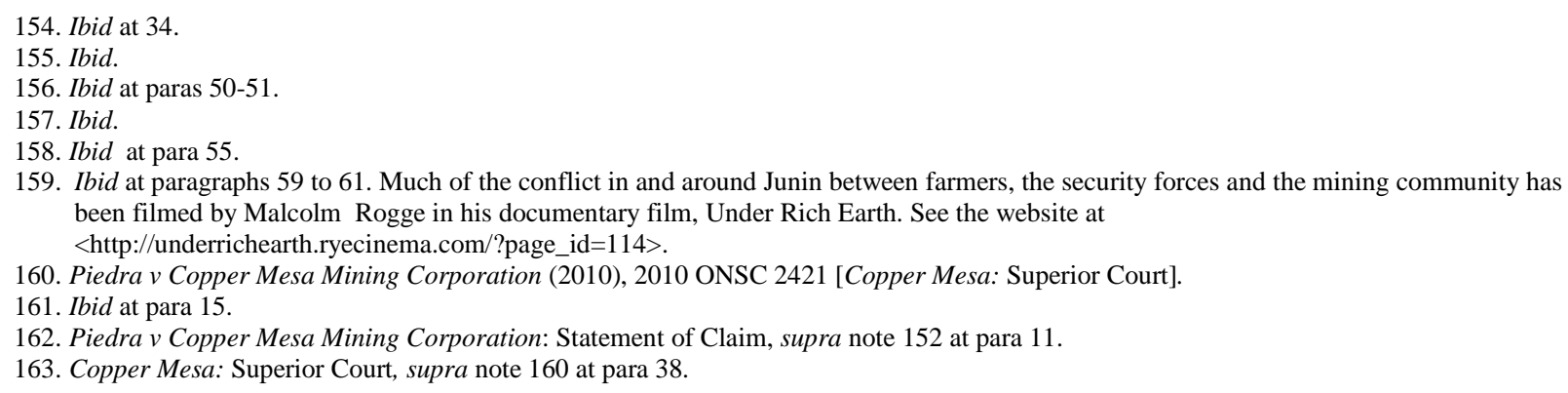


events in Ecuador, which allegedly led to unlawful conduct by agents of Copper Mesa or that the listing would lead to such events, despite the fact that the TSX was warned that the violence would occur.

The Ontario Court of Appeal affirmed the motions judge's reasoning. ${ }^{164}$ The Court found insufficient evidence to hold the directors personally liable, finding that there was no direct connection between acts or omissions of the directors and the harm caused to the plaintiffs. They found that the defendants had only become directors recently and were not involved in the management of the Copper Mesa entities. Although the claimants argued that the directors had been informed and that silence from the directors in the face of the violence amounted to tacit approval of the violence against the plaintiffs, the Court was not sympathetic to this line of argument. $^{165}$

\section{The Three Cases From El Estor}

Members of the Mayan Q'eqchi' communities around the Fenix mine are bringing three related lawsuits in the Ontario Superior Court of Justice against the Canadian mining company HudBay Minerals. The first lawsuit was commenced on September 24, 2010, by the widow and mother of the five children of Adolfo Ich Chamán who was killed during the time of the protests around El Estor in September 2009. As discussed above, the claim alleges that Adolfo Ich was "hacked and shot to death by private security forces employed by CGN near his home in El Estor, Guatemala."166

The claim made by Adolfo Ich's widow is that HudBay, both in Canada and Guatemala, was negligent in deploying security forces into the community of La Unión and in authorizing the use of excessive force in response to the peaceful opposition, despite the corporation being aware that the security personal were unlicensed, using illegal weapons and had in the past used unreasonable violence against local Mayan populations. ${ }^{167}$ Further, the allegation is that HudBay continued to employ under-trained and inadequately supervised security personnel, and,

164. Piedra v Copper Mesa Mining Corporation (2011), 2011 ONCA 191 [Copper Mesa: Court of Appeal].

165. Copper Mesa: Superior Court, supra note 160 at para 46.

166. Choc Statement of Claim, supra note 88.

167. Ibid at para 2. 
regardless of public commitments to the contrary, failed to implement or enforce adequate standards of conduct and oversight which would have prevented the murder of Adolfo Ich. ${ }^{168}$

On the same day that Adolfo Ich was shot, German Chub was shot by the same mine company security personnel. ${ }^{169}$ The then 21 -year-old, single father has been left a paraplegic by the shooting and has lost the use of his right lung. He had not been involved in any protests on that day but was watching a football game at a community football field and was shot without provocation. ${ }^{170}$ On October 26, 2011, German commenced a lawsuit against HudBay Minerals and CGN, similarly alleging that the violence against him was caused by negligent authorization of the deployment of heavily armed security personnel into Mayan Q'eqchi' communities on September 27, 2009. ${ }^{171}$

The final lawsuit against the corporation relates to the forcible evictions of the community of Lote Ocho that took place in January 2007 as discussed above. Eleven women, Margarita Caal Caar, Rosa Elbira Coc Ich, Olivia Asig Xol, Amalia Cac Tiul, Lucia Caal Chun, Carmelina Caal Ical, Irma Yolanda Choc Cac, Elvira Choc Chub, Elena Choc Quib and Irma Yolanda Choc Quib, have commenced an action against HudBay Minerals Inc. and HMI Nickel for the brutal gang rapes by uniformed mining company security personnel, police and military during the forceful expulsion of Mayan Q'eqchi' families. ${ }^{172}$ As a result of these rapes, the claim asserts that some of these women lost their babies and are unable to have children. ${ }^{173}$

The claim alleges that the security forces that committed the rapes were under the control and direction of Canadian mining company Skye Resources which sought the forced eviction in order to clear the land of the Indigenous communities for its Fenix Mining Project. ${ }^{174}$ In 2008, HudBay Minerals bought and merged with Skye Resources (renamed HMI Nickel), which the claim asserts makes HudBay responsible for the past legal wrongs and liabilities of Skye Resources. ${ }^{175}$ The lawsuit alleges that the harm suffered by the plaintiffs was caused by the negligence of Skye Resources in failing to direct and supervise its security personal, knowing that they were unlicensed, and in authorizing the forced evictions without taking reasonable steps

\footnotetext{
168. Ibid at para 37.

169. Chub v HudBay; Amended Statement of Claim filed October 26, 2011, online: 〈http://www.chocversushudbay.com/legal-documents .

170. Ibid at paras $49-55$.

171. Ibid.

172. Caal Statement of Claim, supra note 66.

173. Ibid at paras 65, 66, 67.

174. Ibid at paras 1 and 48 and 49 .

175. Ibid at para 3 .
} 
to control violence against the community, although it made public representations to the contrary. $^{176}$

HudBay has asked the courts dismiss the claims before having a hearing on the merits. At the time of writing, the matter has not gone to court, but HudBay will argue that the proper forum would be in Guatemala and that the Canadian company and directors did not owe a duty of care to the Indigenous people in the El Estor region.

\section{The Context For Judicial Decision-Making in Guatemala}

Like many countries in Latin America, Guatemala has a specialized court to address constitutional issues, derived from the German model. The Court does not deal with civil suits or criminal matters, but rather focuses on ensuring that legislation conforms to the provisions of the Constitution of Guatemala. There are ten members who are appointed for five-year terms. ${ }^{177}$ Described below are two of its decisions with respect to mining in order to illustrate the larger contextual challenges facing the judiciary in Guatemala.

The first decision, from 2008, invalidated a number of provisions of the Mining Act. ${ }^{178}$ The case was brought by Yuri Melini of the Centre for Legal Environmental and Social Action of Guatemala (CALAS), a non-profit organization founded in 2000 and active in research on environmental issues. ${ }^{179}$ Melini has raised concerns about a number of mines. In his application, he challenged a provision in the Mining Act that gave the government thirty days to respond to an environmental assessment submitted by a project proponent. If the government did not respond within this time period, the environmental assessment was deemed to have been approved. This provision is particularly troublesome in Guatemala because of the lack of infrastructure for assessing and monitoring environmental impacts. Only a few years before the Melini proceedings were commenced, there had been an investigation of another Canadian owned mine in Guatemala, by an organ of the International Finance Corporation. In critiquing the environmental assessment done for that mine, the report noted that investigators found "no record of analysis of company capacity nor of government capacity to supervise or regulate the

176. Ibid at paras 2, 29-31, 77-79.

177. For a description of the court and its decisions, see "Corte de Constitucionalidad", online: 〈http://www.cc.gob.gt/>.

178. Expediente $1491-2007$ (1 April 2008), online:

<http://www.cc.gob.gt/siged2009/mdlConsultas/frmVerFichaDocumento.aspx?St_Documentold=812380.html>.

179. CALAS has highlighted the role of mining in environmental degradation and in the displacement of the campesinos from their villages and lands. See their website at Centro de Acción Legal Ambiental y Social de Guatemala, http://www.calas.org.gt/. 
project". ${ }^{180}$ In the Melini decision the Constitutional Court found that provisions in the Constitution of Guatemala related to the protection of the environment and the life and health of the citizens required that there be a review of the environmental impacts. A process that permitted approval of an environmental assessment merely by the passage of time did not meet the constitutional standard.

The second important decision of the Constitutional Court was from 2011 and dealt with title to property near the Fenix project in El Estor. ${ }^{181}$ The case was brought by the community of Agua Caliente Lote Nueve, which was contiguous to Lote Ocho where the evictions occurred in 2007. The community complained about the exploration activities of CGN and said that mining personnel moved boundary stones and made exploration holes, which affected the community's water. $^{182}$ The community asked the Land Foundation ${ }^{183}$ to confirm that it had title to its land. There was a problem with this request, and the story we are about to relate about the resolution to this problem reveals much about the judicial system and about the forces that may be influencing parts of this system.

The facts in this case are pretty clear. Under a land reform act, communities were able to purchase land to hold under communal title. The community in this case began paying for the land in 1985 and was awarded provisional title, conditional on completing the scheduled payments. They made the final payment on July 18, 2002. In 2004 the mine was being transferred from INCO to Skye Resources. On July 2, 2004, the Land Foundation informed the community that the Registry book had been damaged in 1998 and that the pages of the Registry that contained their title were missing. In December 2004, Skye completed the purchase of the concession from INCO. ${ }^{184}$ The Land Foundation told the community that the community would have to go to court to get an order to replace the pages. The same year, the community went to the Ninth Judge of the Civil Trial Court. Their case was rejected because the judge said that they had begun the wrong process for the remedy that they were seeking. The community then went to the Tenth Judge of the Civil Trial Court, but were rejected because the document certifying

180. Compliance Advisor/ Ombudsmen ("CAO"), "Assessment of a Complaint Submitted to CAO in Relation to the Marlin Mining Project in Guatemala" (7 September 2005) at iii, online: CAO <http://www.cao-ombudsman.org/pdfs/CAO-Marlin-assessment-English-7Sep05.pdf>.

181. Expediente 934-2010 (8 Februrary 2011), online: <http://www.cc.gob.gt/siged2009/mdlWeb/frmConsultaWebVerDocumento.aspx?St_DocumentoId=816061.html\&St_RegistrarConsulta=y es\&sF=fraseabuscar>.

182. For photos of Lote 9 see University of Northern British Columbia, "El Estor", online: UNBC <http://blogs.unbc.ca/fieldschools/2008/05/07/el-estor/>.

183. In Spanish, the body is called "Fondo de Tierras" and is responsible for keeping a registry of land titles.

184. See "Skye Resources", online: $24 \mathrm{hGold}<\mathrm{http}: / / w w w .24 \mathrm{hgold} . c o m / e n g l i s h / i n f o c o m p a n y . a s p x ? i d=8985384 E 6680 \&$ market=SKR.TO>. 
the legal status of the representative was illegible. The community returned to the Tenth Judge, who then found that there was no certification that the land claimed was the land that was referred to in the missing pages. In 2007, realizing that the Land Foundation had done nothing to facilitate the proceedings, the community again appealed to the Land Foundation for assistance. They were rebuffed a second time, and told that they needed to get a judicial order. When the community went to the third court, this time the Sixth Judge of the Civil Trial Court, their case was dismissed because the community had failed to provide proof that the missing pages referred to the land that they were claiming. The community returned to the Land Foundation to ask them to replace the pages, and they were told a third time that a court order was necessary. Finally, the community began a constitutional proceeding, arguing that their constitutional rights had been violated because of the refusal of the Land Foundation to confirm their title.

The first level of hearing on a constitutional application went to the Court of Appeals on February 15, 2010. This was a year after HudBay had been considering reactivating the mine and had been trying to have Indigenous occupants removed. The decision at the Court of Appeals was a disaster. The judge found that the community already had title confirmed on February 17, 2004 and that the Land Foundation had replaced the missing pages, pursuant to an order from the Fifth Judge of the Civil Trial Court on December 20, 2004. Consequently, there was no basis for the proceeding. The judge ordered costs against the community and fined the lawyer 1,000 quetzales (approximately \$130) for bringing the proceeding. The recounting of events by the judge of the Court of Appeals is very different from the story that we have recounted above, which involved the community being shunted back and forth between the courts and the Land Foundation. This is because the judge of the Court of Appeals based his decision on the documents from another community, Agua Caliente Sexan Lote Once.

The community appealed this decision, and was able to present its case to the Constitutional Court itself in 2010. The Court found in the community's favour, and confirmed that the Court of Appeals had relied on mistaken documents. The Constitutional Court reviewed documents that confirmed that the provisional title had been awarded in 1985 and documents that confirmed that the final payment had been made. The judges came to the conclusion that the only step remaining was the administrative act of confirming title. While the legislation did not stipulate who had the obligation to get a court order when pages of a registry went missing, the Court concluded that, in these circumstances, the obligation was with the Land Foundation and 
not the community. The Court then ordered that the missing pages be replaced, showing confirmation of title of the land to the community.

Why was it so difficult for the community to have this administrative step taken? The key documents were always available. The Land Foundation had the documentation of the first provisional title and proof of the last payment, which should have triggered the administrative steps to finalize the title. Before speculating on the explanation, we would like to describe the general context in which these decisions are made.

South America went through a dark period of brutal dictatorships during the 1980s. Countries like Chile, Argentina and Peru have confronted their past and some of the dictators are now being prosecuted or are in jail. The situation is different in Guatemala. Here, the country is still living with the power of the military and its dictators. There are strong democratic forces in Guatemala and there are individuals in government, the military and the churches who wish to move forward. However, the former dictators did not have to flee the country or face any legal accounting. In fact, they continue to run for office. Rios Montt, the dictator during the worst period of violence in Guatemala in the early 1980s, was the elected President of Guatemala's Congress in 1999. In January 2012, Guatemala elected a new president, Otto Perez Molina, who was a general in the civil war. According to the Huffington Post:

Perez, who was a top military official during the war, has long insisted there were no massacres, human rights violations or genocide in a conflict that killed 200,000 civilians, mostly Mayan Indians. $^{185}$

In June 2012, Perez Molina began closing down Guatemala's Peace Archives Directorate, which had been instrumental in investigating atrocities committed during the civil war. ${ }^{186}$

Those who cross the military are in danger. The 1998 report on the civil war released by Monsignor Juan Gerardi, mentioned earlier, was sharply critical of the military. Two days after the release of the report, Gerardi was beaten to death outside of his home. At first, the police and government authorities attempted to cast the blame on an attempted robbery, then on a domestic dispute and then an attack by a dog. After a concerted effort by the Catholic Church and international agencies, individuals connected with the military were charged. There were death

185. Romina Ruiz-Goiriena, "Otto Perez Molina, New Guatemala President Wants to Regain US Military Aid” (12 January 2012) online: Huffington Post <http://www.huffingtonpost.com/2012/01/12/otto-perez-molina-guatemala-president-wants-us-aid_n_1202781.html>. 186. "GHRC Denounces Closure of Peace Archives Directorate in Guatemala" (4 June 2012), online: Guatemala Human Rights Commission/USA <http://ghrcusa.wordpress.com/category/ghrc/>. 
threats against witnesses and others involved in the process, and in 2001 the prosecutor, Leopoldo Zeissig, and the trial judge, Yasmin Barrios, were forced to flee the country. ${ }^{187}$

In 2002, the colonel who ordered the death of the forensic anthropologist Myrna Mack in 1990 was finally sentenced, but he was freed by a lower court only a year later. Despite a new Supreme Court ruling that reinstated his conviction after public and international pressure, the colonel has eluded custody. ${ }^{188}$

The pattern of violence has now spread to those who express concerns over mining development. In 2008, the Procuraduría de los Derechos Humanos (Human Rights Ombudsman) had to investigate death threats against nine environmentalists, including the Minister of Environment. ${ }^{189}$ Shortly after the Constitutional Court released its 2009 decision striking down parts of the Mining Act, which we described above, the plaintiff, Dr. Yuri Melini, was shot seven times in his stomach and legs on a Guatemala City street. The Guatemalan police have not yet found those who perpetrated the crime nor have they established a conclusive motive. However, Dr. Melini commented that "(t)he most obvious, logical position is that the attack had something to do with my stand against the rampant mining in my country, given the timing of the attack.",190 We have recounted the history of violence at El Estor. The controversial Marlin Mine owned by Canadian company Goldcorp has also been associated with violence. The mine began in 1999, a few months after the murder of Monsignor Juan Gerardi. A few years later, Bishop Álvaro Ramazzini, who led a march against the mine, received death threats and had to be put under government protection. ${ }^{191}$ There were death threats against other anti-mine activists and a car belonging to one of the leaders was set on fire. ${ }^{192}$ More recently, in 2010, two men from the San Miguel community shot Diodora Hernández in the head. ${ }^{193}$ Ms. Hernández, who has

187. "Guatemala lawyer flees death threats" BBC News (30 July 2001), online: BBC News <http://news.bbc.co.uk/2/hi/americas/1465512.stm>.

188. "International Court Condemns Guatemala over Murder" Reuters News (19 December 2003).

189 "Investigan amenazas en contra de nueve ambientalistas, incluido ministro" (23 September 2008), online: <http://www.adn.es/printVersion/ADNNWS20080923_2475/4>. See also, "IV Informe Nacional sobre Violaciones a los Derechos Humanos de Ambientalistas y Activisatas Ambientale, 2009-2011", online: <http://www.calas.org.gt/images/PDF/informe.pdf>.

190. See Shawn Pogatchnik, "Guatemalan Anti-Mining Activist Wins Rights Prize", ABC News (8 May 82009 ) online: <http://abcnews.go.com/International/wireStory?id=7535268> on Jan 31, 2010; See "Business and Human Rights", Amnesty International, online: <http://www.amnesty.ca/blog.php?blog=bhr_blog\&month=9\&year=2008> on Jan 31, 2010; "Guatemala's Government and civil society condemn attack on environmentalist Yuri Melini", Guatemala Times (5 September 2008) online: Guatemala Times <http://www.guatemala-times.com/news/guatemala/343-guatemalas-government-and-civil-society-condemn-attack-on-environmentalistyuri-melini.html> on Jan 31, 2010.Also see Paola Hurtado, "Algún sentido tiene que estar aquí" El periodico (12 January 2010), online: El periodico < http://www.elperiodico.com.gt/es/20090125/domingo/88024/?t $>$.

191. Kelly Patterson, "Canadian Mine Strikes Lode of Unrest: The Debate over the Presence of a Gold Mine in Guatemala has Resulted in a Call for 'Urgent Action' by Amnesty International" Ottawa Citizen (26 April 2005).

192. Ibid.

193. Goldcorp Inc, Public Letter, "Letter From Goldcorp Inc. To Rights Action And ADISMI: Concerning Shooting Of Maya Protesters At Marlin Mine In Guatemala" (20 July 2010) online: Indigenous Peoples Issues <http://indigenouspeoplesissues.com/index.php?option=com content\&view=article\&id=6349:letter-from-goldcorp-inc-to-rights-actionand-adismi-concerning-shooting-of-maya-protesters-at-marlin-mine-in-guatemala\&catid=30\&Itemid=63> . 
resisted selling her property to Goldcorp and participated in demonstrations against Marlin, lost her right eye but has made an incredible recovery. ${ }^{194}$ According to sources in Guatemala, the two men were both associated with the Marlin mine at the time, one a former employee and the other working for a contractor. ${ }^{195}$ In June of 2010, Carmen Mejía, another campaigner against the Marlin mine, is reported to have received death threats. ${ }^{196}$

Incidents like these are reported at distressingly regular intervals in Guatemala. By way of illustration, as we were finalizing this chapter, two incidents were reported in two days. On June, 12, 2012 according to the K'iche' People's Council, one of its council members, José Tavico Tzunun was killed by two heavily armed men who entered his property at about one in the morning. Tzunun was active in organizing a referendum in his community, Santa Cruz del Quiché, against a dam proposed by a Spanish company. Days earlier, he had received death threats saying "If you continue bringing the people together for meetings, you will pay the consequences."197 A day later, on June 13, 2012, the Guatemala Human Rights Commission/USA reported that an outspoken advocate for community consultation, Yolanda "Yoli" Oquely Veliz, 33, was shot three times by men on a motorcycle. She had been active in opposing the El Tabor gold mine, owned by Radius Gold of Canada, and had received death threats over the past month. ${ }^{198}$

\section{THE CONSEQUENCES OF IMPUNITY}

There is a gap in the global mechanisms that hold transnational corporations accountable for their actions. In the case of Anvil Mining, a United Nations investigation found that the company provided support for the soldiers that participated in the massacre. Yet no jurisdiction took responsibility for addressing the issue. In 2005, the operating profit, after depreciation and amortization, for the Dukulushi mine, which was closest to the site of the massacre a year earlier,

194. "Shooting of Community Leader Opposing Goldcorp Inc.'s Marlin Mine in Guatemala; Threats Against Local Leaders Escalate" (13 July 2010), online: Mining Watch <http://www.miningwatch.ca/urgent-action-shooting-community-leader-opposing-goldcorp-incs-marlin-mineguatemala-threats-against>.

195. Goldcorp Inc, Public Letter, supra note 193.

196. Amnesty International, "Individuals at Risk: Carmen Mejía; Threatened with death for defending her community" online: Amnesty Canada $\langle$ http://www.amnesty.ca>.

197. "Member of K'iche' People’s Council Murdered”, online: <http://nisgua.blogspot.ca/2012/06/member-of-kiche-peoples-council.html>. For information on the community referendum that organized eighty communities for a vote in October, 2010, see "Santa Cruz del Quiche: Reorganizing Historic Resistance", online: <http://nisgua.blogspot.ca/2010/11/santa-cruz-del-quiche-reorganizing.html>

198. See Guatemala Human Rights Updates, online: <http://ghrcusa.wordpress.com>; "Guatemalan female activist shot for leading blockade against a Canadian-owned gold mine" (14 June 2012), online: MiMundo <http://www.mimundo.org/2012/06/14/2012-06-guatemalanfemale-activist-shot-for-leading-blockade-against-a-canadian-owned-gold-mine/>. 
was $\$ 18.7$ million. Its overall revenue for the DRC rose from \$29 million in 2004 to almost \$69 million in 2005. ${ }^{199}$ In the case of Cambior, the spill was described by the Canadian judge as "one of the worst environmental catastrophes in gold mining history." 200 Yet the case was dismissed in Guyana, ${ }^{201}$ and Cambior continued to operate profitably until 2005 when the mine was exhausted. $^{202}$

So what happened around the Fenix mine in El Estor? Skye Resources said that the evictions were peaceful although houses were burned. HudBay and Skye Resources refer to the Indigenous people as squatters and illegal occupants. However, the original occupants of the land had been removed in 1968 and 1970 for INCO and an ILO committee found that the Indigenous people had not been consulted before the granting of an exploration licence to Skye in 2004. So perhaps the question of who is the "illegal occupier" is not clear. HudBay points out that in 2009 an arrest warrant was issued for the head of CGN's security force for the killing of Adolfo Ich, but that three of the four witnesses against him have since recanted. ${ }^{203}$ Perhaps the women did voluntarily recant, but given the context of violence surrounding the mines, a reasonable person would be hard pressed not to pause and ponder.

And how to explain the case of Lote Nueve? The sequence of events defies a coherent explanation. Why was the title to the community's land thrown into limbo for seven years when the evidence that fulfilled the conditions for title was readily available? Why did three lower court judges throw the case out on what appear to be technicalities? Why did the judge at the Court of Appeals base his decision on the wrong papers and why would the lawyers for the Land Foundation and lawyers for CGN ask the Constitutional Court to uphold a decision that was clearly based on mistaken documents?

There are a lot of other, more general, questions that can be asked about much of the violence surrounding Canadian mining projects in Guatemala. Is the appearance that violence is targeted at environmentalists and community activists only the result of an unfortunate culmination of isolated acts of over-enthusiastic mine supporters? Is there something that the mining companies should be doing to ensure that the mine does not directly or indirectly benefit from the violence and intimidation of its opponents? Are there circumstances when the mining

\footnotetext{
199. Anvil Mining Ltd. Annual Report 2005 at 6, online: Anvil Mining: 〈http://www.anvilmining.com/files/2005-anvilannualreport.pdf>. 200. Cambior, supra note 136.

201. "Cambior Inc: Omai Lawsuit Struck and Dismissed" CNN Money (October 31, 2006 ), online: <http://money.cnn.com/news/newsfeeds/articles/marketwire/06178759.htm>.

202. Guyana Office for Investment, "Mining", online: 〈http://www.goinvest.gov.gy/mining.html>.

203. HudBay, "The Facts", supra note 66.
} 
companies should decide that Indigenous people have a legitimate claim to the land, and that the project should not proceed? In this chapter, we are not purporting to have the answers, but rather suggesting that there should be a process established to bring the truth to light.

Canadian courts do have the ability to fill the void. Lawyers for the Canadian government stated to a Committee of Parliament:

Legal remedies to address environmental or human rights violations can also arise from civil rather than criminal law. To the extent that crimes or wrongs, such as damage to the environment or personal injuries, committed outside Canada also constitute claims of the sort cognizable as a tort, civil law remedies may be available to the foreign plaintiff in Canadian courts. As such, Canadian corporations or their directors and employees may be pursued in Canada for their wrongdoing in foreign countries. ${ }^{204}$

The courts should consider the frailty of the judicial system that is embedded in the backdrop of violence in Guatemala and ponder the possibility that, for now, Canada might provide the only forum for the truth to be determined and responsibility attributed appropriately. In the Anvil case, the Quebec Court of Appeal could have applied the forum of necessity exception, ${ }^{205}$ under which the court has residual discretion to assume jurisdiction if there is no other forum in which the plaintiff can reasonably seek relief and there is a sufficient connection with the jurisdiction in which the plaintiff seeks to have the case tried. In the Cambior case, the court found that it had jurisdiction and could have allowed the trial to go ahead in Canada. Perhaps the result would have been the same. On the other hand, the result from the court in Guyana is exactly the result that the plaintiffs predicted.

With respect to the duty of care, it would be odd that profits could travel freely from Guatemala to Canada, while the Canadian beneficiaries would not have to take responsibility for how that money is raised or what activities occur in order to produce the profits. The Ontario Court of Appeal in Copper Mesa confirmed as much and was clear in saying that there was no absolute immunity for the Canadian entities. There could be circumstances where a duty of care might be established. However, no responsibility was attributed in this case. One of the major gaps that the Court found in the Copper Mesa case was that the communications by the community were not deemed to have been specific enough to cause the defendants to foresee

204. Standing Committee on Foreign Affairs and International Trade (SCFAIT), "Fourteenth Report: Mining in Developing Countries-Corporate Social Responsibility", supra note 105.

205. Civil Code of Quebec, SQ 1991, c 64, article 3136. 
harm. However, these reports from the community should be viewed in the context of a tumultuous history both with the government and with mining interests in general. For example, in the cases against HudBay Minerals the court should look at the historical and current pattern of violence in order to determine whether a reasonable person would foresee that greater care needed to be exercised in order to prevent bloodshed.

In a globalized world, encouraging ethical behaviour cannot be left to a single jurisdiction or a single institution. We hope that the time will come when Canadian courts begin to participate in creating the mechanisms necessary to close the gap in corporate accountability. In the words of retired Supreme Court of Canada justice, Ian Binnie, "Applying our law to situations outside of our territory is contrary to our custom; but there are acts that are so repugnant that they must force us to rethink our law." 206

206 «Appliquer notre droit à des situations à l'extérieur de notre territoire est contraire à nos conceptions; mais il y a des actes tellement répugnants qu'ils doivent nous forcer à revoir nos conceptions du droit. Au XVIIIe siècle, la piraterie posait une telle menace qu'on pouvait juger les pirates sans égard au lieu de leurs crimes.», quoted in "Limpunité de nos sociétés minières", La Presse, 05 novembre $2012 . \quad$ Online: http://www.lapresse.ca/debats/chroniques/yves-boisvert/201211/04/01-4590272-limpunite-de-nos-societesminieres.php (informal translation by author). 